\section{4 括}

ジアルキルスズオキシド $\left(\mathrm{R}_{2} \mathrm{SnO}, \mathrm{R}=\mathrm{CH}_{3}, n-\mathrm{C}_{4} \mathrm{H}_{9}\right)$ と酶酸エス テルとの反応によりトリアルキルスズ型化合物を得たが, エステ ルのかわりに高級アルコール $\left(\mathrm{R}^{\prime} \mathrm{OH}\right)$ を用いても，収率良くト リチルキルスズアルコキシドを生成することがわかった。後者の 反応では中間に $\mathrm{R}^{\prime} \mathrm{O}\left(\mathrm{R}_{2} \mathrm{SnO}\right)_{n} \mathrm{R}^{\prime}(n=1,2, \cdots)$ が生成され, こ れが熱分解をらけたものと考えられる。 $\mathrm{R}=n-\mathrm{C}_{4} \mathrm{H}_{9}$ では概して $n \geqq 2$ 型のものの方が, $n=1$ 型のものよりもトリブチルスズア ルコキシドを生成しやすいが， $n=1$ 型のものでも熱分解を十分 に行えば，ブチル基の不均化がおこり目的物を生成した。
$\mathrm{R}=\mathrm{CH}_{3}$ では $n=1$ 型のものは単離することができず, これは $n \geqq 2$ 型のものにくらべ熱的に不安定で, 容易にメチル基の不均 化がおこったものと考えられる。これを支持する結果として, ジ メチルスズジメトキシド単独のあるいは，これにジメチルスズオ キシドを添加した系の熱分解において，トリメチルスズメトキシ ドの収率にはほとんど差はなく定量的であり, また, ジメチルス ズジクロリドとナトリウムアルコキシド $\left(\mathrm{RONa}, \mathrm{R}=n-\mathrm{C}_{6} \mathrm{H}_{13}, n-\right.$ $\left.\mathrm{C}_{8} \mathrm{H}_{17}\right)$ との反応生成物の熱処理においても, トリメチルスズア ルコキシドのみが定量的に得られ, ジメチルスズジアルコキシド は認められなかった。

\title{
金，銀，白金，パラジゥムのナフテネートおよびビスオキシムパラジウムジクロリドの合成
}

(昭 和 43 年 12 月 7 日受理)

\author{
滝 口 利 夫*1 - 黒 崎 勝 利 ${ }^{* 2}$. 阿 部 光 雄 ${ }^{* 1}$
}

ナフテン酸ナトリウムと貴金属塩（塩化金酸, 塩化金酸カリウム, 塩化白金酸, テトラクロロパラジゥム酸, 硝酸銀) との反応 により金, , 銀, 白金, パラシ்ムののナフテネートを合成した。またテトラクロロパラジムム酸とオキシム（フセトキシム，フセ トアルドキシム, メチルエチルケトンオキシム, メチルイソブチルケトンオキシム, ベンズフルドキシム, フルフラルドキシム, シクロヘキサノンオキシム) より $\left(\mathrm{RR}^{\prime} \mathrm{C}: \mathrm{NOH}\right)_{2} \mathrm{PdCl}_{2}$ なる一般式で表わされる一連のビスオキシムパラジゥムジクロリドを合 成した。生成物の多くは文献に記載のない安定な結晶性物質であり何れる熱分解によって対応する金属を析出する。

\section{1 楮 言}

焼成により導電性金属面を形成する導電塗料，あるいはガ ス, 陶磁器等の装飾用貴金属の分野においてはその素材として古 来, テルペン類の一硫化物と貴金属塩の反応により得られるいわ ゆる貴金属バルサム1) が賞用されその後メルカプチド2) 特に 3 級 メルカプチドを主成分とするものが提唱された。著者等は従来よ りこの分野における新しい素材となる貴金属化合物の検討を行な い既報9)において複素環チオール， $N, N$-ジオルガノジチオカル ハミン酸の貴金属 (Pd, Ag， Au) 誘導体を主体とした一連の実 験結果を報じた。

その後の研究においてイオウを含まない新素材の開発を目的と し各種のカルボキシレート, キレート化合物の検討を行なってき たがいくつかのモノオキシムのパラジウム化合物, 白金, 金, 銀，パラジウムのナフテネートが実用上の諸条件*3 の多くを充た

*1 Toshio TAKIGUCHI, Mitsuo ABE 群馬大学工学部合成 化学科：桐生市天神町.

*2 Katsutoshi KUROSAKI 昭栄化学工業株式会社：東京都 練馬区豊玉北.

*3 合成上の充分な再現性, 収率, 生成物の安定性, 有機溶剂 に対する溶解性, 添加助剂 $(\mathrm{Bi}, \mathrm{Cr}, \mathrm{Rh}$ 口ジネート) と の相溶性, 狫成面の連続性.

1) F. Chemnitius, Sprechsaal, 60, 182 (1927) ; P. P. Budnikoff, Ber., 55, 3848 (1922) ; 中土, 工化, 60, 694 (1957)；中土, 化学の領域, 3, 503 (1949).

2) B.P., 934182(1959); 日特公, 4980(1961)；2955(1962)； 12846 (1963)； 15342 (1965).

3）滝口, 浅田, 中込, 阿部, 黒崎, 工化, 70, 1182 (1967).
すことをみとめた。貴金属ナフテネートについては従来 $\mathrm{Ag}, \mathrm{Au}$ について断片的な記録があるのみであり，またビスオキシムパラ ジウムクロリドについてはビスアセトキシムパラジウムジクロリ ド)について簡単な記載があるのみで, それ以外のものはいずれ も文献末知の新物質であるので, 合成に関する二, 三の知見とと もに以下に報告する。

\section{2 実験ならびに結果}

\section{$2 \cdot 1$ オキシムの合成}

アセトン (bp $\left.56^{\circ} \mathrm{C}\right)$, メチルエチルケトン (bp 79 80 8 ), メ チルイソブチルケトン (bp 115 116 ${ }^{\circ} \mathrm{C}$ ), アセトアルデヒド (bp

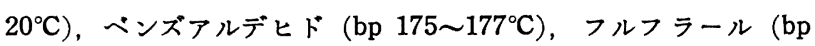
$160 \sim 161^{\circ} \mathrm{C}$ ) は市販品を精製, 上記沸点のものを用いた。これら のアルデヒド, ケトンよりヒドロキシルアミン塩酸塩（あるいは 硫酸塩）との反応でほぼ同様の操作で対応するオキシムを得た。 一例をフルフラルドキシムにつき略記する。ヒドロキシルアミン 塩酸塩 $35 \mathrm{~g}(0.5 \mathrm{~mol})$ を $150 \mathrm{ml}$ の蒸留水に溶解, これに水酸 化ナトリウム $20 \mathrm{~g}(0.5 \mathrm{~mol})$ を少量ずつ加えて溶解, 擤找しつ つ $48 \mathrm{~g}(0.5 \mathrm{~mol})$ のフルフラールのエーテル溶液を滴下する。 エーテル層を分離, 水洗したのち減圧でエーテルを除き黄白色粗 結晶を得た。これを石油エーテルから再結晶して $51 \mathrm{~g}(92 \%) の$ フルフラルドキシムを $\mathrm{mp} 71 \sim 72^{\circ} \mathrm{C}$ の白色針状結晶として得 た。他のオキシムも, 同様にして得た。すなわち, アセトキシム $\left(\mathrm{mp} \mathrm{58} 59^{\circ} \mathrm{C}\right)$, メチルエチルケトンオキシム $\left(\mathrm{bp} 29^{\circ} \mathrm{C} / 3 \mathrm{mmHg}\right)$,

4) A. V. Babaeva, I. I. Lyuboshits, Doklady Acad. Nauk S.S.S.R., 89, 681 (1953). 
メチルイソブチルケトンオキシム (bp $30 \sim 31^{\circ} \mathrm{C} / 3 \mathrm{mmHg}$ ), ベン ズアルドキシム $\left(\mathrm{mp} 35^{\circ} \mathrm{C}\right)$, アセトアルドキシム $\left(\mathrm{mp} 44 \sim 45^{\circ} \mathrm{C}\right)$ である。シクロヘキサノンオキシムは市販品を精製, mp 89〜90 ${ }^{\circ} \mathrm{C}$ のものを用いた。 $\mathrm{KBr}$ 錠剤法あるいは液膜法によるこれらオ キシム類の $\mathrm{NaCl}$ 領域における赤外吸収スペクトルは, いずれも $\mathrm{C}=\mathrm{NOH}$ による吸収帯として 1645〜1685 $\mathrm{cm}^{-1}\left(\nu_{\mathrm{C}=\mathrm{N}}\right), 925 \sim$ $955 \mathrm{~cm}^{-1}\left(\nu_{\mathrm{N}-\mathrm{O}}\right)$ にそれぞれ鋭い吸収を示した。

\section{$2 \cdot 2$ 責金属塩水溶液の調製}

硝酸銀は市販品を用い $\mathrm{Ag}=10 \%$ 水溶液とした。塩化金酸は 粒状金より常法5)により調製， $\mathrm{Au}=10 \%$ の水溶液とした。また これより塩化金酸カリウムを調製, 同一濃度の水溶液とした。パ ラジウム塩は純金属を $0.1 \mathrm{~mm}$ に圧延, 脱脂処理した後王水に 溶解, 脱硝をくりかえし, $\mathrm{Pd}=10 \%$ のテトラクロロパラジウム 酸6) 水溶液とした。白金はパラジウムと同様の操作で $\mathrm{Pt}=10 \%$ の塩化白金酸夏) 水溶液, および塩化白金酸カリウム ${ }^{6)}$ 水溶液とし た。

\section{$2 \cdot 3$ 貫金属塩とオキシムとの反応}

2.3.1 バラジウム化合物 メチルイソブチルケトンオキシム 誘導体の合成を例にとり詳記する。

パラジウム $5 \mathrm{~g}$ を含む前記水溶液を約倍量の蒸留水で希釈, かきまぜメチルイソブチルケトンオキシム $16.1 \mathrm{~g}$ (0.14 mol)の クロロホルム溶液を滴下する。水層は徐々に裉色しクロロホルム 層は暗橙色となる。必要に応じクロロホルムを追加し液温を 40 ${ }^{\circ} \mathrm{C}$ に保ち約 1 時間かきまぜると水層はほとんど無色となりパラ ジウムイオン*4の存在を示さなくなる。水層を傾瀉で徐き, 数回 $30^{\circ} \mathrm{C}$ の温水でクロロホルム層を水洗, 水溶上で乾固して黄橙色 微結晶塊を得た。これを り再結晶して $\mathrm{mp} 188 \sim 190^{\circ} \mathrm{C}$ の黄色結晶 $16.9 \mathrm{~g}$ を得た。分析 值 $\mathrm{Pd}^{* 5}=26.0 \%, \mathrm{~N}=6.8 \%, \mathrm{Cl}^{* 6}=17.9 \%$ ，赤外吸収スペクト ルよりビスメチルイソブチルケトンオキシムパラジウムジクロリ ドと同定した。 $\left(\mathrm{CH}_{3} \cdot \mathrm{C}_{4} \mathrm{H}_{9} \mathrm{C}: \mathrm{NOH}\right)_{2} \mathrm{PdCl}_{2}$ に対する計算值は $\mathrm{Pd}$ $=26.1 \%, \mathrm{~N}=6.9 \%, \mathrm{Cl}=17.2 \%$ である。

同様の操作で得られたパラジウム化合物は次のとおりであり, 融点, $\mathrm{Pd} \%, \mathrm{~N} \%, \mathrm{Cl} \%$ の順に列記する。なお [ ]内の数字は ビスオキシムパラジウムジクロリドに対する計算值を示す。

ビスアセトアルドキシムパラジウムジクロリド：150 160 （分解）；35 36 [36.1]；10.2 [9.5]；22.2 [23.8］；ビスアセ卜 キシムパラジウムジクロリド：227〜 $229^{\circ} \mathrm{C} ; 33.3$ [32.9] ; 8.6 [8.7]；19.6 [21.7], ビスメチルエチルケトンオキシムパラジウ ムジクロリド：184 186 ${ }^{\circ} \mathrm{C} ; 29.6[30.3] ； 7.7$ [8.0]；19.4[20.0], ビスベンズアルドキシムパラジウムジクロリド：97〜 $104^{\circ} \mathrm{C}$; 26.0 [25.4]；6.4 [6.7]；16.0 [16.7]，ビスフルフラルドキシム パラジウムジクロリド : 208 211 ${ }^{\circ} \mathrm{C} ; 26.2[26.6] ; 6.6$ [7.0]; 17.0[17.6] ; ビスシクロヘキサノンオキシムパラジウムジクロリ

*4 ジメチルグリオキシムのエタノール溶液で定性した.

*5 $800^{\circ} \mathrm{C}$ 焼成による重量法, 硝酸分解物に対するジメチルク リオキシムキレートによる重量法を併用した.

*6 ステンレスボンベ中で $\mathrm{Na}_{2} \mathrm{O}_{2}$ で分解, 塩素イオンの定量 によった。

5）永井，久保編 “工業楽品事典”，日刊工業新聞社(1964）p. 119.

6）日本化学会編，“実験化学講座（第 9 巻）無機化合物の合成 と精製”，丸善 (1958) p. 370 .
ド : 197 $199^{\circ} \mathrm{C} ; 26.0$ [26.4]; 6.8 [7.0]；17.5 [17.4]。これら パラジウム化合物はいずれも安定な結晶性固体であり, 再結晶を くりかえした純品についてのX線粉末回折図を同定上の資料とし て記録した。すなわち,

$\left(\mathrm{CH}_{3} \cdot \mathrm{C}_{4} \mathrm{H}_{9} \mathrm{C}: \mathrm{NOH}\right)_{2} \mathrm{PdCl}_{2}$

$\begin{array}{rrrrrr}I / I_{0} & 1.00 & 0.27 & 0.09 & 0.11 & 0.07 \\ d, \mathrm{KX} & 9.12 & 5.68 & 5.34 & 4.65 & 4.58\end{array}$

$\left(\mathrm{CH}_{3} \mathrm{CH}: \mathrm{NOH}\right)_{2} \mathrm{PdCl}_{2}$

$\begin{array}{rrrrr}I / I_{0} & 0.34 & 0.49 & 0.73 & 1.00 \\ d, \mathrm{KX} & 4.51 & 5.67 & 6.15 & 8.43\end{array}$

$\left[\left(\mathrm{CH}_{3}\right)_{2} \mathrm{C}: \mathrm{NOH}\right]_{2} \mathrm{PdCl}_{2}$

$I / I_{0} \quad 0.35 \quad 1.00$

$\begin{array}{lll}d, \mathrm{KX} & 7.38 & 7.01\end{array}$

$\left.\left(\mathrm{CH}_{3} \cdot \mathrm{C}_{2} \mathrm{H}_{5} \mathrm{C}: \mathrm{NOH}\right)_{2} \mathrm{PdCl}_{2}\right)$

$I / I_{0} \quad 0.23 \quad 0.50 \quad 1.00 \quad 0.40$

$\begin{array}{lllll}d, \mathrm{KX} & 5.95 & 7.26 & 7.92 & 8.35\end{array}$

$\left(\mathrm{C}_{6} \mathrm{H}_{5} \mathrm{CH}: \mathrm{NOH}\right)_{2} \mathrm{PdCl}_{2}$

$\begin{array}{llll}I / I_{0} & 1.00 & 0.44 & 0.34\end{array}$

$\begin{array}{lllll}d, \mathrm{KX} & 9.21 & 5.37 & 5.28\end{array}$

$\left(\mathrm{C}_{4} \mathrm{H}_{3} \mathrm{OCH}: \mathrm{NOH}\right)_{2} \mathrm{PdCl}_{2}$

$\begin{array}{rrrrrr}I / I_{0} & 1.00 & 0.49 & 0.57 & 0.45 & 0.44 \\ d, \mathrm{KX} & 9.73 & 8.48 & 5.25 & 4.98 & 4.90\end{array}$

$\left(\mathrm{C}_{6} \mathrm{H}_{10}: \mathrm{NOH}\right)_{2} \mathrm{PdCl}_{2}$

$\begin{array}{lllll}I / I_{0} & 0.58 & 0.21 & 1.00 & 0.71\end{array}$

$\begin{array}{lllll}d, \mathrm{KX} & 5.51 & 6.81 & 8.35 & 8.82\end{array}$

これらパラジウム化合物の有機溶剂に対する溶解性はジメチル スルホキシド, ジメチルホルムアミドに易溶, クロロホルム、ア セトンに可溶でありエーテル, トルェン, ベンゼンに難溶, へキ サンに不溶であった。パラジウムより算出した収率は平均 $86 \%$ であった。

$2 \cdot 3 \cdot 2$ 金, 白金, 銀化合物 塩化金酸水溶液中にアセトンオ キシムのクロロホルム溶液を滴下，かきまぜると水層は徐々に脱 色されクロロホルム層が黄橙色に着色する。水層が無色になるま でオキシム溶液を加えた後クロロホルム層を分離, 水洗, 減圧下 でクロロホルムを除いて褐色油状物を得た。生成物は $200^{\circ} \mathrm{C}$ 近辺 に加熱すると急速に分解して金を析出する。他のオキシムもほぼ 同様の生成物を与えるが，これらの金化合物はいずれも光に対し て不安定であり，直射日光のもとでは数時間で大部分の金を微粒 子状に析出する。溶液の場合も同様であり 1 昼夜の放置で容器内 面に金鏡を生ずる。白金, 銀についても同様の実験を試みたが白 金の場合は数時間の㩖找においても水層の脱色がみられず，又銀 の場合は大部分の銀イオンが水層に残留し，パラジウムの場合の ような安定な錯化合物の生成がみられなかった。

\section{$2 \cdot 4$ ナフテネートの合成}

2.4.1 ナフテン酸およびナトリウムナフテネート 原料ナフ テン酸は bp $117 \sim 133^{\circ} \mathrm{C} / 3 \mathrm{mmHg}$ の範囲にあり $n_{\mathrm{D}}^{25}=1.4842$, 中和当量よりの分子量 ${ }^{* 7}$ は $290 \sim 310$ であり, 炭素数 $17 \sim 18$ 程 度のシクロパラフィンモノカルボン酸の混合物と推足される。液 膜法による $\mathrm{NaCl}$ 領域の赤外吸収スペクトルもこの構造を支持す る。原料ナフテン酸を等容のエタノールと混合, これに当量の水

*7 1.4 シオキサン中の水点法に上る分子量は平均 297 を示 す. 
酸化ナトリウムを加えて約 8 時間加熱還流し，水と任意の割合で 白濁することなく混合するに到ったものを爾後の反応に用いた。 生成物は淡褐色透明な粘稠液体であり無機酸で中和すると原料ナ フテン酸を再生する。

\section{$2 \cdot 4 \cdot 2$ 貫金属ナフテネート}

銀ナフテネート：ナトリウムナフテネート $49.3 \mathrm{~g}$ (約 0.15 $\mathrm{mol})$ のエタノール溶液 $100 \mathrm{~m} l$ を常温で攢找しつつこれに硝酸 銀 $17 \mathrm{~g}(0.1 \mathrm{~mol})$ を含む水溶液 $150 \mathrm{ml}$ を約 1 時間にわたって 滴下する。硝酸銀の滴下とともに徐々に白色沈殿を生成する。得 られた沈殿は 2 回エタノールで洗浄, 減圧下で乾燥して $59.8 \mathrm{~g}$

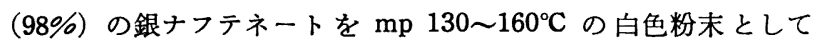
得た。テトラヒドロフランより再結晶した白色微結晶は mp 167 $\sim 173^{\circ} \mathrm{C}$ であり $\mathrm{Ag} \%$ は重量法, 容量法ともに $26.7 \sim 27.3$ の 範囲にあり，原料ナフテン酸の分子量に対応した值を示す。へキ サン, エタノール，アセトンに不溶でありテトラヒドロフラン, クロロホルム, トルェンに可溶であった。銀ナフテネートのクロ ロホルム溶液は $500 \sim 550^{\circ} \mathrm{C}$ の加熱によりガラス面上に光輝ある 連続性銀面を形成する。充分洗浄, 乾燥した銀塩は光に対してか なり安定であり6ケ月の保存においても変色, 溶解度の変化等を みとめない。

金ナフテネート：塩化金酸水溶液とナトリウムナフテネートの 直接の反応は再現性に乏しく収率*8, 生成物のAu\%が一定しな い。金ナフテネートの満足すべき合成は塩化金酸カリウムとの反 応また場合によりアンモ二ヤ水の併用により達せられた。一例を

*8 特に高濃度の反応に拁いては金の析出が著しい。
次に記す。

ナトリウムナフテネートの $42 \%$ エタノール溶液 $132 \mathrm{~g}$ に 28 $\%$ アンモニヤ水 $30 \mathrm{~g}$ を加兄蒸留水で $500 \mathrm{ml}$ に希釈する。 40 $\sim 45^{\circ} \mathrm{C}$ に保温, 擋找しつつこれに $\mathrm{Au}=10 \%$ の塩化金酸カリウ ム水溶液 $110 \mathrm{~g}$ を約 1 時間にわたって滴下する。徐々に黄褐色 沈殿が生成する。全量を加えた後液温を $70 \sim 75^{\circ} \mathrm{C}$ とし, 約 1 時 間䚓拌をつつけると生成物は褐色油状物となり水層は無色透明と なる。水層を傾瀉で除き油状物をクロロホルムで希釈，水洗をく りかえした後クロロホルム溶液を約半量に濃縮, これをアセトン 中に滴下すると登黄色粉末が沈殿する。これをロ別, 乾燥して, $\mathrm{Au}=40 \%$ の金ナフテネート $72.1 \mathrm{~g}(97 \%)$ を得た。融点は 147 ～ $155^{\circ} \mathrm{C}$ でありクロロホルム, ジブチルアミンに易溶, ラペンダ 一油, トルエンに可溶, ナフテン酸に熱時可溶, エーテル, エタ ノール，アセトンに難溶であった。金ナフテネートのクロロホル ム, ジブチルアミン溶液は $400 \sim 450^{\circ} \mathrm{C}$ の加熱によりガラス上に 光輝ある金面を形成する。

白金, パラジウムナフテネート：塩化白金酸, テトラクロロパ ラジウム酸とナトリウムナフテネートとの直接の反応はともに金 属の析出が著しく良好な結果を与えない。金の場合に準じてアン モニヤ水を併用することによってほぼ同様の過程でともに黒色粘 稠な油状物を得た。金属含有量は, パラジゥムについては 9 10 \%, 白金については 11〜13\%であった。何れもクロロホルム, トルエン, ラペンダー油等の植物精油に易溶であり, これらの溶 液は 300 400 C の加熱で光輝ある金属面をガラス上に形成する。 